\title{
Response of the Maternal, Fetal, and Neonatal Pituitary-Thyroid Axis to Thyrotropin-Releasing Hormone $^{1}$
}

\author{
FERNANDO MOYA, PATRICIA MENA, FELIPE HEUSSER, ARNALDO FORADORI, \\ ENRIQUE PAIVA, RICARDO YAZIGI, PATRICIO MICHAUD, AND IAN GROSS \\ Division of Perinatal Medicine, Department of Pediatrics, Yale University, New Haven, Connecticut [F.M., I.G.]; \\ Hospital Sotero del Rio, Puente Alto, Chile [P.M., E.P., R.Y.]; and Departments of Pediatrics, Nuclear Medicine, \\ and Endocrinology, Universidad Catolica de Chile, Santiago, Chile [F.H., A.F., P.M.]
}

\begin{abstract}
Thyrotropin releasing hormone (TRH) readily crosses the placenta and stimulates the fetal pituitary. We studied the response of the maternal and fetal pituitarythyroid axes to TRH and the influence of prenatal exposure to TRH on the physiological postnatal increase in thyrotropin (TSH) and triiodothyronine $\left(\mathrm{T}_{3}\right)$ in the neonate. Twenty-six pregnant women received TRH $(400$ or $600 \mu \mathrm{g})$ intravenous or saline (controls) either 2 or $12 \mathrm{~h}$ before elective cesarean section at term. Administration of $400 \mu \mathrm{g}$ of TRH resulted in significant elevations of maternal TSH $(15.7 \pm 2.9$ versus $3.2 \pm 0.4 \mu \mathrm{U} / \mathrm{ml}, p<0.01)$ and prolactin $(416 \pm 94$ versus $223 \pm 41 \mathrm{ng} / \mathrm{ml}, p<0.05) 2 \mathrm{~h}$ later. Maternal $T_{3}$ remained unchanged. A higher dose of TRH $(600 \mu \mathrm{g})$ produced comparable results. Maternal administration of TRH $(400 \mu \mathrm{g}) 2 \mathrm{~h}$ before delivery resulted in significant increases in fetal TSH and $\mathrm{T}_{3}$ over controls (21.1 \pm 3.7 versus $4.8 \pm 1.0 \mu \mathrm{U} / \mathrm{ml}$, and $132 \pm 12$ versus $64 \pm 9 \mathrm{ng} / \mathrm{dl}, p<0.01$, respectively). Cord blood hormone levels 12 hours after TRH administration were similar to controls. Higher doses of TRH did not produce further increases in fetal TSH or $\mathrm{T}_{3}$. Control and treated neonates demonstrated similar physiological postnatal increases in TSH and $T_{3}$, suggesting that prior exposure to TRH did not blunt this response. These data suggest that maternal administration of TRH is an effective way of increasing fetal $T_{3}$ levels, and that this treatment does not inhibit the postnatal surge in $\mathrm{TSH}$ and $\mathrm{T}_{3}$. (Pediatr Res 20: 982-986, 1986)
\end{abstract}

\section{Abbreviations}

RDS, respiratory distress syndrome $T_{3}$, triiodothyronine

$T_{4}$, thyroxine

TSH, thyrotropin

TRH, thyrotropin releasing hormone

PRL, prolactin

For more than a decade glucocorticoids have been administered to women in premature labor to prevent RDS in the neonate (1-4). Glucocorticoids require $24-48 \mathrm{~h}$ in order to be

Received March 31, 1986; accepted May 22, 1986.

Address for correspondence and requests for reprints Fernando R. Moya, M.D., Department of Pediatrics, Yale University School of Medicine, 333 Cedar Street, New Haven, CT 06510

' Portions of this study were presented at the Society for Pediatric Research Meeting, Washington, D.C., May 6-10, 1985, and published in abstract form (Pediatr Res 19:189A, 1985). effective so that delivery of the infant often takes place before any beneficial effect can occur (3). In addition, glucocorticoids may be less effective in very immature and in male fetuses (2$5)$. Several investigators have proposed the use of thyroid hormones to enhance fetal lung maturation but results with this approach have been less favorable than those observed with glucocorticoids $(6-8)$. Since there is little transplacental passage of $\mathrm{T}_{3}, \mathrm{~T}_{4}$, or TSH (9-11), these studies have involved intraamniotic administration of thyroid hormones.

Recent evidence suggests that glucocorticoids and thyroid hormones acts synergistically to enhance fetal lung maturation (1214). The combined hormone regimen also induces a more rapid acceleration of surfactant production in human fetal lung in culture than steroids alone (15). For these reasons, the use of combined hormonal treatment with glucocorticoids and thyroid hormones to enhance fetal lung maturation has been proposed $(14,15)$. Such treatment could involve the use of TRH, which, unlike thyroid hormones, crosses the placenta readily and evokes secretion of fetal TSH, $\mathrm{T}_{3}$, and $\mathrm{T}_{4}$ in humans and laboratory animals (16-18). TRH alone also has been shown to increase surfactant secretion in fetal rabbits (19).

In anticipation of the clinical use of TRH to induce fetal lung maturation, we conducted a pilot study to determine the timing and extent of the maternal and fetal responses to TRH and the influence of fetal exposure to TRH on the normal postnatal surge in TSH and thyroid hormone levels $(20,21)$.

\section{MATERIALS AND METHODS}

Normal pregnant women about to undergo elective cesarean section at term at the Hospital Sotero del Rio, Chile, were eligible for the study. After obtaining consent, one group of women was injected intravenously with either one $\mathrm{ml}$ of normal saline, the diluent in the TRH preparation (controls, $n=6$ ), TRH (Thypinone, Abbott Laboratories, North Chicago, IL) $400 \mu \mathrm{g}(n=8)$, or TRH $600 \mu \mathrm{g}(n=5), 2 \mathrm{~h}$ before delivery. Another group of women was injected with $400 \mu \mathrm{g}$ of TRH twelve hours before delivery by cesarean section $(n=7)$. After the intravenous injection, the maternal vital signs were monitored closely. Uterine contractility and fetal heart rate (Corometrics, Wallingford, CT) were continuously monitored in most instances until the time of the cesarean section. Immediately after delivery, a sample of arterial blood from the umbilical cord was obtained for determination of blood gases and glucose.

Hormonal determinations. Samples of blood were drawn from the mothers just before the intravenous injection of saline or TRH, and at 30 and 120 min thereafter. Cord blood was collected at the time of delivery. Samples of $1.5 \mathrm{ml}$ of venous blood from the neonates were obtained at 1,2 , and $6 \mathrm{~h}$ after birth and the 
serum was frozen at $-20^{\circ} \mathrm{C}$ until analysis. All serum samples were measured at least in duplicate in the same assay. $T_{3}$ levels were measured by radioimmunoassay by the method of Chopra et al. (22). TSH and PRL levels also were determined by radioimmunoassay using the following standards: TSH, NIH AFP 2426-C, and PRL, WHO 1st IRP 68/38 lyophilized in human serum.

Statistical analyses were performed by analysis of variance with the Student-Newman-Keuls test. All values are presented as mean \pm SEM.

The study was approved by the Human Investigation Committee of Yale University, the Universidad Catolica de Chile, and the Hospital Sotero del Rio, Chile.

\section{RESULTS}

A total of 26 pregnant women at term and their newborns was studied. As shown in Table 1, there were no differences in gestational age and birth weight among the groups. All infants had Apgar scores above 7 at 1 and $5 \mathrm{~min}$ after birth. The umbilical arterial blood gas values and glucose concentrations in cord blood were not different in the various groups. After slow intravenous injection of TRH no increases in maternal blood pressure were observed, nor were abnormalities of uterine contractility or fetal heart rate noted.

Maternal response to TRH. The changes observed in the maternal serum levels of $\mathrm{TSH}, \mathrm{T}_{3}$, and $\mathrm{PRL}$, after administration of TRH are shown in Table 2 . There were significant increases

Table 1. Neonatal data*

\begin{tabular}{lccc}
\hline & Control & TRH-2 h $\dagger$ & TRH-12 h $\ddagger$ \\
\hline No. of patients & 6 & 13 & 7 \\
Wt & $3240 \pm 380$ & $3558 \pm 464$ & $3428 \pm 351$ \\
Gestational age & $39.1 \pm 1.3$ & $39.3 \pm 3.1$ & $39.5 \pm 0.6$ \\
Cord arterial blood & & & \\
$\quad$ gases & & & \\
pH & $7.33 \pm 0.07$ & $7.34 \pm 0.06$ & $7.37 \pm 0.08$ \\
$\mathrm{PaO}_{2}$ & $19 \pm 9$ & $20 \pm 6$ & $19 \pm 8$ \\
$\mathrm{PaCO}_{2}$ & $39 \pm 7$ & $36 \pm 5$ & $40 \pm 8$ \\
Base deficit & $-4.2 \pm 2$ & $-4.4 \pm 3$ & $-1.4 \pm 2$ \\
Cord blood glucose & $55 \pm 2$ & $47 \pm 4$ & $50 \pm 4$ \\
$\quad$ (mg/dl) & & & \\
\hline
\end{tabular}

* All neonates had Apgar scores at 1 and $5 \mathrm{~min}>7$.

$\dagger$ Infants delivered $2 \mathrm{~h}$ after administration of $400 \mu \mathrm{g}(n=8)$ or 600 $\mu \mathrm{g}(n=5)$ of TRH.

$\ddagger$ Infants delivered $12 \mathrm{~h}$ after administration of TRH.

Table 2. Maternal levels of $\mathrm{TSH}, \mathrm{T}_{3}$, and prolactin after administration of TRH

\begin{tabular}{lccc}
\hline & \multicolumn{3}{c}{ Time after administration (min) } \\
\cline { 2 - 4 } & 0 & 30 & 120 \\
\hline TSH $(\mu \mathrm{U} / \mathrm{ml})$ & & & \\
Controls & $2.4 \pm 0.2$ & $2.8 \pm 0.1$ & $2.2 \pm 0.2$ \\
TRH $400 \mu \mathrm{g}$ & $3.2 \pm 0.4$ & $15.7 \pm 2.9^{*}$ & $7.7 \pm 1.2^{*}$ \\
TRH $600 \mu \mathrm{g}$ & $3.2 \pm 0.3$ & $16.2 \pm 2.9^{*}$ & $10.7 \pm 2.2^{*}$ \\
T $_{3}(\mathrm{ng} / \mathrm{dl})$ & & & \\
Controls & $252 \pm 23$ & $235 \pm 25$ & $195 \pm 19$ \\
TRH $400 \mu \mathrm{g}$ & $198 \pm 15$ & $205 \pm 5$ & $252 \pm 37$ \\
TRH $600 \mu \mathrm{g}$ & $179 \pm 19$ & $197 \pm 32$ & $219 \pm 41$ \\
Prolactin $(\mathrm{ng} / \mathrm{ml})$ & & & \\
Controls & $203 \pm 20$ & $229 \pm 51$ & $183 \pm 32$ \\
TRH $400 \mu \mathrm{g}$ & $223 \pm 41$ & $416 \pm 94 \dagger$ & $215 \pm 59$ \\
TRH $600 \mu \mathrm{g}$ & $241 \pm 49$ & $527 \pm 136^{*}$ & $184 \pm 38$ \\
\hline
\end{tabular}

$* p<0.01$ when compared to baseline value of same group by analysis of variance with Student-Newman-Keuls test.

$\dagger p<0.05$ when compared to baseline value of same group by analysis of variance with Student-Newman-Keuls test. in TSH and PRL $30 \mathrm{~min}$ after the injection of $400 \mu \mathrm{g}$ of TRH. TSH levels remained elevated $2 \mathrm{~h}$ after TRH administration, whereas PRL levels returned to baseline. Administration of 600 $\mu \mathrm{g}$ of TRH did not result in further increases in TSH or PRL levels. No differences were found in $\mathrm{T}_{3}$ levels 30 and $120 \mathrm{~min}$ after the administration of TRH.

Fetal response to TRH. Cord blood levels of TSH, $\mathrm{T}_{3}$, and PRL are shown in Table 3. In the control group, the mean fetal serum TSH level was significantly higher than the corresponding maternal level $(4.8 \pm 1.0$ vs $2.2 \pm 0.2 \mu \mathrm{U} / \mathrm{ml}, \mathrm{p}<0.05)$. Conversely, the mean fetal serum $\mathrm{T}_{3}$ level was lower in the fetuses than in their mothers $(64.7 \pm 9.4$ versus $195.8 \pm 19.3 \mathrm{ng} /$ $\mathrm{dl}, p<0.01$ ). Maternal administration of $400 \mu \mathrm{g}$ of TRH $2 \mathrm{~h}$ prior to delivery resulted in a 4-fold increase in fetal TSH levels above control values $(21.1 \pm 3.7$ versus $4.8 \pm 1.0 \mu \mathrm{U} / \mathrm{ml}, p<$ 0.01 ). Fetal $\mathrm{T}_{3}$ levels $2 \mathrm{~h}$ after TRH administration also were significantly elevated when compared to controls $(132.5 \pm 12.6$ versus $64.7 \pm 9.4 \mathrm{ng} / \mathrm{dl}, p<0.01)$. Although the mean fetal PRL level was higher in treated fetuses, this difference was not statistically significant. Maternal administration of $600 \mu \mathrm{g}$ of TRH 2 $\mathrm{h}$ prior to delivery produced similar results. When $400 \mu \mathrm{g}$ of TRH were administered to the mother $12 \mathrm{~h}$ prior to delivery, no elevation of cord blood TSH, $\mathrm{T}_{3}$, or PRL was detected (Table 3 ).

In addition, two women in premature labor between 32 and $33 \mathrm{wk}$ of gestation were given $400 \mu \mathrm{g}$ of TRH 2 to $3 \mathrm{~h}$ prior to delivery. The cord blood TSH levels were 34 and $27 \mu \mathrm{U} / \mathrm{ml}$ and the $\mathrm{T}_{3}$ levels were 108 and $115 \mathrm{ng} / \mathrm{dl}$, respectively. These values are similar to those obtained in TRH-treated full term infants. There was also a further increase of TSH and $\mathrm{T}_{3}$ after birth.

Postnatal changes of TSH and $T_{3}$. The postnatal changes in the serum levels of TSH and $\mathrm{T}_{3}$ in infants born to mothers given saline or TRH 2 or $12 \mathrm{~h}$ prior to delivery are shown in Figures 1 and 2.

All infants exhibited the physiological increase in TSH and $\mathrm{T}_{3}$ levels after birth, but there were no significant differences in these levels among the various groups at 1,2 , or $6 \mathrm{~h}$ after birth.

\section{DISCUSSION}

Thyrotropin-releasing hormone stimulates TSH and PRL release by the pituitary in a dose-dependent fashion $(23,24)$. Maximal increases in serum TSH are observed after intravenous injection of $400-500 \mu \mathrm{g}$ of TRH to normal humans of both sexes (24). Administration of TRH to pregnant women, in doses betwen $200-500 \mu \mathrm{g}$, have been reported to result in a severalfold increase in maternal serum TSH levels and a less marked rise in serum PRL concentrations (25-27). These observations were confirmed in our study where injection of $400 \mu \mathrm{g}$ of TRH resulted in approximately a 5 -fold increase in maternal serum TSH levels and a doubling of serum PRL levels. When doses of $600 \mu \mathrm{g}$ of TRH were administered, no further stimulation was observed. These findings suggest that the maximal response to TRH is not significantly altered during pregnancy.

Maternal serum $T_{3}$ levels increase during gestation and rise even further during labor in humans and nonhuman primates $(16,17,28)$. Azukizawa et al. (16) reported that $2 \mathrm{~h}$ after

Table 3. Cord blood (fetal) levels of TSH, $T_{3}$, and prolactin

\begin{tabular}{ccccc}
$\begin{array}{c}\text { Group/Time of } \\
\text { exposure }\end{array}$ & $n$ & $\begin{array}{c}\text { TSH } \\
(\mu \mathrm{U} / \mathrm{ml})\end{array}$ & $\begin{array}{c}\mathrm{T}_{3} \\
(\mathrm{ng} / \mathrm{dl})\end{array}$ & $\begin{array}{c}\text { Prolactin } \\
(\mathrm{ng} / \mathrm{ml})\end{array}$ \\
\hline $\begin{array}{c}\text { Controls } \\
\mathrm{TRH} 400\end{array}$ & 6 & $4.8 \pm 1.0$ & $64.7 \pm 9.4$ & $159 \pm 39$ \\
$\mu \mathrm{g} / 2 \mathrm{~h}$ & 8 & $21.1 \pm 3.7^{*}$ & $132.5 \pm 12.6^{*}$ & $304 \pm 81$ \\
$\begin{array}{c}\mathrm{TRH} 600 \\
\mu \mathrm{g} / 2 \mathrm{~h}\end{array}$ & 5 & $22.9 \pm 4.0^{*}$ & $124.8 \pm 12.5^{*}$ & $243 \pm 26$ \\
$\begin{array}{c}\mathrm{TRH} 400 \\
\mu \mathrm{g} / 12 \mathrm{~h}\end{array}$ & 7 & $3.4 \pm 0.2$ & $59.8 \pm 8.2$ & $185 \pm 17$ \\
\hline
\end{tabular}

* Statistically significant difference from control values, $p<0.01$ by analysis of variance and Student-Newman-Keuls test. 


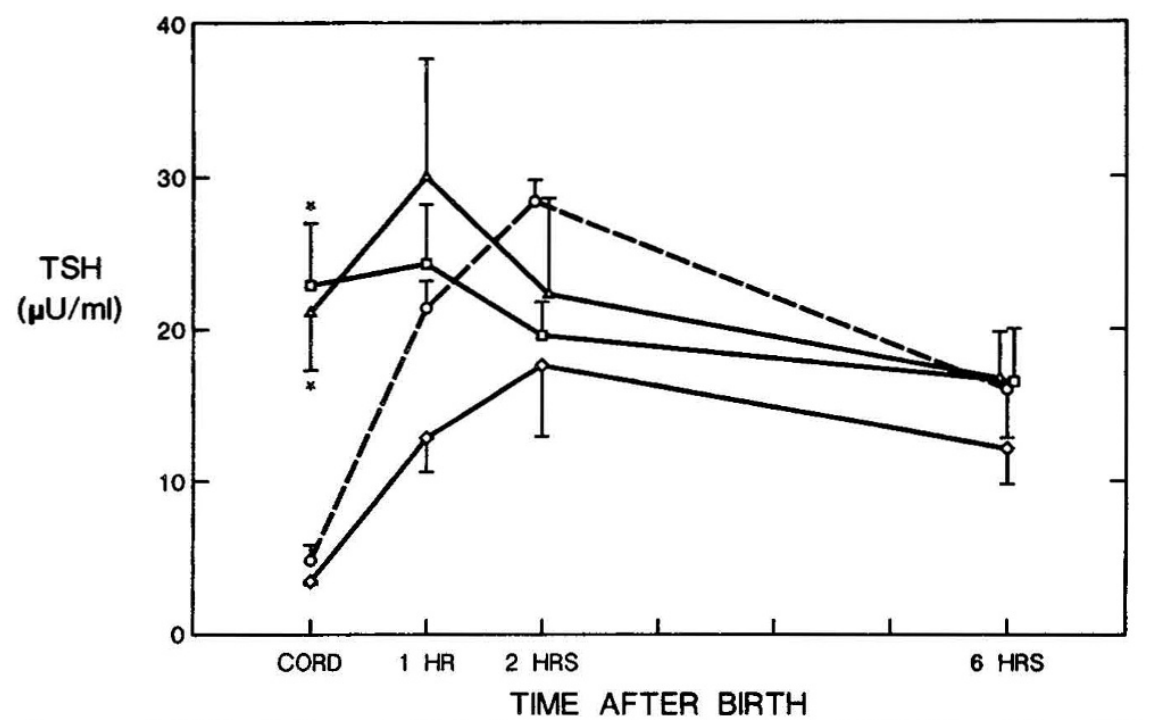

Fig. 1. Postnatal changes in serum TSH levels in control infants $(O)$, in those exposed to TRH $400 \mu \mathrm{g}(\triangle)$ or $600 \mu \mathrm{g}(\square)$ given $2 \mathrm{~h}$ prior to delivery, and those exposed to TRH $400 \mu \mathrm{g}$ given $12 \mathrm{~h}$ prior to delivery $(\diamond) .^{*} \mathrm{p}<0.01$ by ANOVA and Student-Newman-Keuls test.

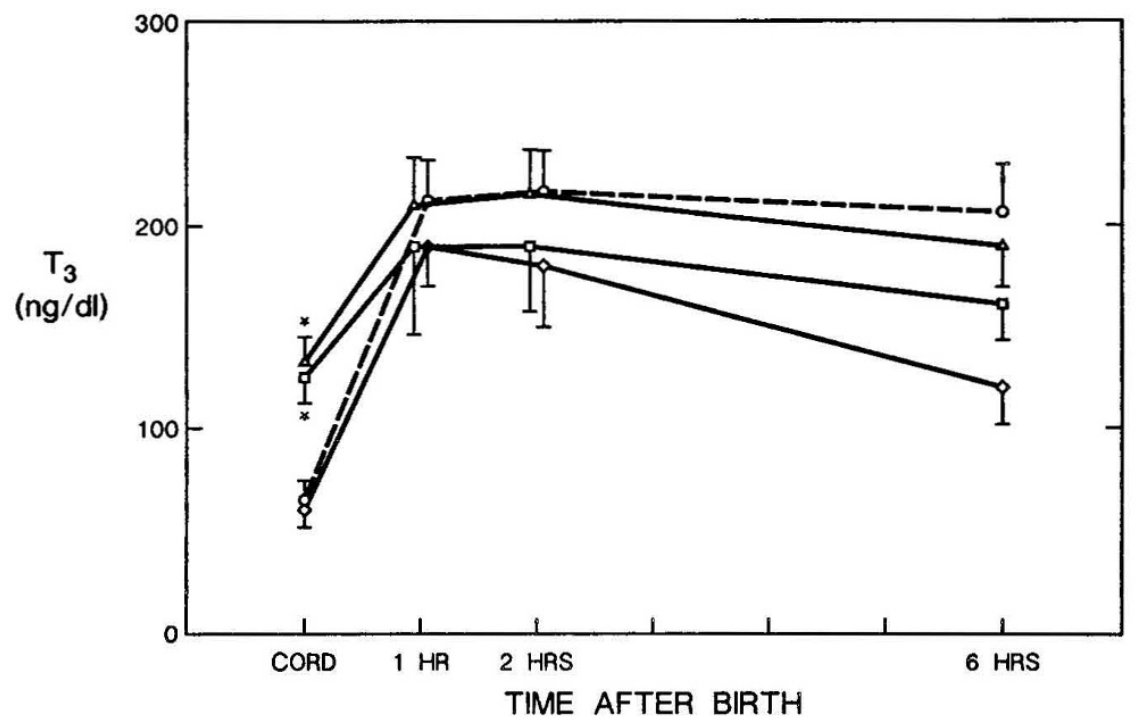

Fig. 2. Postnatal changes in serum $T_{3}$ levels in control infants $(O)$, in those exposed to TRH $400 \mu \mathrm{g}(\triangle)$ or $600 \mu \mathrm{g}$ ( $\square$ ) given $2 \mathrm{~h}$ prior to delivery, and those exposed to TRH $400 \mu$ g given 12 h prior to delivery $(\diamond) .{ }^{*} p<0.01$ by ANOVA and Student-Newman-Keuls test.

administration of TRH to preterm pregnant rhesus monkeys, there was an increase of about $50 \%$ in serum $\mathrm{T}_{3}$ levels. This increase was more pronounced in nonpregnant rhesus monkeys. More recently, however, Miyamoto (27) reported a failure to observe changes in serum $\mathrm{T}_{3}$ levels 30 and $90 \mathrm{~min}$ after the administration of $500 \mu \mathrm{g}$ of TRH to pregnant women at term. Our data are consistent with the latter observation in that we found no change in maternal serum $\mathrm{T}_{3} 2 \mathrm{~h}$ after administering doses of TRH that maximally stimulate the pituitary.

Pregnancy can alter the response of the pituitary to stimulation with TRH. For instance, the relative increase in PRL after TRH administration is relatively lower during pregnancy, whereas the $\mathrm{TSH}$ response is largely unchanged (25). Whether the response of the maternal thyroid to TRH-induced TSH secretion decreases at term when maternal serum $T_{3}$ levels are considerably higher than in early pregnancy is unclear (28). Also it is possible that in our study a hemodilution effect secondary to fluid administration before epidural anesthesia for cesarean section might have obscured small increases in serum $\mathrm{T}_{3}$ levels after the TRH injection.

Mild short-term side effects of the administration of TRH to pregnant women and normal controls have been reported (24, $25)$. They include nausea, desire to void, and small changes in blood pressure. In a study involving pregnant rhesus monkeys, increased uterine contractility was observed in one of eight animals after infusion of TRH (16). Other studies, however, have not reported any side effects in either mother or fetus $(26,27)$. In our study, no maternal or fetal side effects were observed.

Many authors have shown that the placenta is relatively impermeable to TSH and thyroid hormones, and that significant maternal/fetal gradients of these hormones exist; the serum TSH levels are lower and the serum $\mathrm{T}_{3}$ levels are higher in the mother as compared to the fetus $(16,17,27,29,30)$. Our results are in agreement with these previous findings. Administration of large amounts of $T_{3}$ or $T_{4}$ to the mother is necessary in order to increase the fetal levels of these hormones, as less than $5 \%$ of the amount given crosses the placenta $(9,10,13,17)$. This can be partially explained by the active placental conversion of $T_{4}$ to reverse $T_{3}$, and $T_{3}$ to $3,3^{\prime}$ diiodothyronine, mediated by a placental inner ring iodothyronine deiodinase $(31,32)$. Intraamniotic injection of thyroid hormones, however, does result in higher fetal levels (33). TRH, on the other hand, crosses the placenta readily and stimulates the fetal pituitary (16-18).

Azukizawa et al. (16) and Melmed et al. (17) administered a bolus of TRH to the pregnant rhesus monkey before term, and 
demonstrated that the fetus had a greater increase in serum TSH and $\mathrm{T}_{3}$ levels than the mother. TRH-induced PRL release, however, was more pronounced in the mother. We observed a 5-fold increase in maternal serum TSH levels 30 min after TRH infusion, followed by a decrease to levels two to three times the baseline values $90 \mathrm{~min}$ later. The PRL response was less pronounced and of short duration. The fetal serum TSH, however, was still markedly elevated $2 \mathrm{~h}$ after maternal administration of $\mathrm{TRH}$, and fetal serum $\mathrm{T}_{3}$ levels at this time were also significantly elevated when compared to control values. Fetal serum PRL levels were slightly higher than control levels but did not reach statistical significance. It is possible that the fetal PRL levels were elevated prior to delivery, as the PRL levels peak at 30-60 min after TRH administration.

Roti et al. (18) also found that maternal administration of TRH resulted in peak fetal serum TSH values 40-60 min after the infusion; thereafter serum TSH showed a steady decline. Maximal stimulation of the fetal thyroid occurred about $2 \mathrm{~h}$ after the maternal injection of TRH. In this study, the increase of maternal TSH levels induced by TRH administration was less pronounced than that observed in the fetuses. Therefore the authors concluded that the fetal pituitary was more sensitive to TRH than its maternal counterpart. Many factors may contribute to the more marked response of the fetal pituitary-thyroid axis to TRH. Accumulation of TSH in the pituitary gland of the fetus has been observed late in gestation (30), and the TRHinduced TSH surge is less suppressible by $\mathrm{T}_{3}$ in the fetus (17): Besides the increased responsiveness of the fetal pituitary, a lower level of TRH-degrading activity, may allow for a more sustained pituitary stimulation (34).

A marked increase in serum TSH, PRL, and $\mathrm{T}_{3}$ levels normally occurs soon after delivery in full-term neonates $(20,30)$. Preterm infants also exhibit a postnatal increase in serum TSH and $\mathrm{T}_{3}$ levels, but it can be less marked than that of term neonates, particularly in those infants who develop $\operatorname{RDS}(21,35)$. At least part of this response seems to be due to an increase in TRH, but the response also is related to neonatal cooling and cutting of the umbilical cord $(30,36)$. In addition, the postnatal increase in serum $\mathrm{T}_{3}$ levels can be only partly accounted for by increased secretion; it may also reflect increased peripheral conversion of $T_{4}$ to $T_{3}$ instead of reverse $T_{3}$ (37). In our study, the postnatal increase in TSH and $\mathrm{T}_{3}$ occurred in control infants and in those exposed to TRH 2 or $12 \mathrm{~h}$ prior to delivery. The $1 \mathrm{~h}$ levels of these hormones were similar in the treated and control groups despite the fact that the cord-blood values of both $\mathrm{TSH}$ and $\mathrm{T}_{3}$ were significantly higher in the TRH-treated patients. Thus, prenatal administration of TRH does not seem to suppress the physiological postnatal response of the pituitary-thyroid axis. Intraamniotic administration of $\mathrm{T}_{4}$, however, can reduce the postnatal surge of TSH (33).

Evidence supporting a faster and more marked acceleration of fetal lung maturation by the combination of glucocorticoids and thyroid hormones as opposed to glucocorticoids alone has accumulated recently (12-15). Liggins et al. (38) have shown that there is a more profound enhancement of fetal lung maturation in lambs exposed to a combination of glucocorticoids, $T_{3}$, and PRL than when only one or two of these hormones are used. Maternal administration of TRH at term results in fetal serum $\mathrm{T}_{3}$ levels that approximate the concentrations required to stimulate surfactant synthesis in fetal-human lung in organ culture (15). Premature monkey fetuses and preterm infants also respond to $\mathrm{TRH}$ with increases in serum TSH and $\mathrm{T}_{3}$ to levels that may enhance lung maturation $(16,17,38,39)$. Even higher fetal $\mathrm{T}_{3}$ levels may result from the concomitant use of glucocorticoids and TRH (40).

Since administration of TRH during pregnancy does not seem to result in significant side effects in the mother or fetus, or in suppression of the postnatal surge of TSH and thyroid hormones, this therapy may be useful clinically to accelerate fetal lung maturation. Enhanced surfactant secretion already has been demonstrated in fetuses of pregnant rabbits injected with TRH (19). Whether maternal administration of TRH, alone or in combination with glucocorticoids, will be more effective for the prevention of RDS than current glucocorticoid therapy remains to be investigated.

Acknowledgments. The authors thank B. J. Green, Abbott Laboratories, for supplying the TRH, Rhonda Criscuolo and Debbie Camputaro for secretarial assistance, and the midwives and nurses of the Hospital Sotero del Rio for their technical assistance.

\section{REFERENCES}

1. Liggins GC, Howie RN 1972 A controlled trial of antepartum glucocorticoid treatment for prevention of the respiratory distress syndrome in premature infants. Pediatrics 50:515-525

2. Taeusch HW, Frigoletto F, Kitzmiller J, Avery ME, Hehre A, Fromm B, Lawson E, Neff R 1979 Risk of respiratory distress syndrome after prenatal dexamethasone treatment. Pediatrics 63:64-72

3. Ballard RA, Ballard PL, Granberg JP, Sniderman S 1979 Prenatal administration of betamethasone for prevention of respiratory distress syndrome. $J$ Pediatr 94:97-101

4. Collaborative group on antenatal steroid therapy 1981 Effect of antenatal dexamethasone administration on the prevention of respiratory distress syndrome. Am J Obstet Gynecol 141:276-286

5. Papageorgiou A, Colle E, Farri-Kostopoulos E, Gelfand M 1981 Incidence of respiratory distress syndrome following antenatal betamethasone: role of sex, type of delivery, and prolonged rupture of membranes. Pediatrics 67:614617

6. Mashiach S, Barkai G, Sack J, Stern E, Goldman B, Brish M, Serr D 1978 Enhancement of fetal lung maturity by intraamniotic administration of thyroid hormone. Am J Obstet Gynecol 130:289-293

7. Mashiach S, Barkai G, Sack J, Stern E, Brish M, Goldman B, Serr DM 1979 The effect of intraamniotic thyroxine administration on fetal lung maturity in man. J Perinat Med 7:161-170

8. Schreyer P, Caspi E, Letko Y, Ron-El R, Pinto N, Zeidman JL 1982 Intraamniotic triiodothyronine instillation for prevention of respiratory distress syndrome in pregnancies complicated by hypertension. J Perinat Med 10:2733

9. Fisher DA, Lehman H, Lackey C 1964 Placental transport of thyroxine. J Clin Endocrinol 24:393-400

10. Raiti S, Holzman GB, Scott RL, Blizzard RM 1967 Evidence for the placental transfer of triiodothyronine in human beings. N Engl J Med 277:456-459

11. Fisher DA, Hobel CJ, Garza R, Pierce C 1970 Thyroid function in the preterm fetus. Pediatrics 46:208-216

12. Smith BT, Sabry K 1983 Glucocorticoid-thyroid synergism in lung maturation: a mechanism involving epithelial-mesenchymal interaction. Proc Natl Acad Sci USA 80:1951-1954

13. Gross I, Dynia D, Wilson C, Ingleson L, Gewolb I, Rooney S 1984 Glucocorticoid-thyroid hormone interactions in fetal rat lung. Pediatr Res 18:191196

14. Ballard PL 1984 Combined hormonal treatment and lung maturation. Semin Perinatol 8:283-292

15. Ballard PL 1986 Hormone interactions. In: Ballard PL (ed) Hormones and Lung Maturation. Springer-Verlag, Berlin, pp 322-345

16. Azukizawa M, Murata Y, Ikenoue T, Martin Jr CB, Hershman J 1976 Effect of thyrotropin-releasing hormone on secretion of thyrotropin, prolactin, thyroxine, and triiodothyronine in pregnant and fetal rhesus monkeys. J Clin Endocrinol Metab 43:1020-1028

17. Melmed S, Harada A, Murata Y, Socol M, Reed A, Carlson H, Azukizawa M, Martin C, Jorgensen E, Hershman J 1979 Fetal response to thyrotropinreleasing hormone after thyroid hormone administration to the rhesus monkey: Lack of pituitary suppression. Endocrinology 105:334-341

18. Roti E, Gnudi A, Braverman L, Robuschi G, Emanuele R, Bandini P, Benassi L, Pagliani A, Emerson CH 1981 Human cord blood concentrations of thyrotropin, thyroglobulin, and iodothyronines after maternal administration of thyrotropin-releasing hormone. J Clin Endocrinol Metab 53:813817

19. Rooney S, Marino P, Gobran L, Gross I, Warshaw J 1979 Thyrotropinreleasing hormone increases the amount of surfactant in lung lavage from fetal rabbits. Pediatr Res 13:623-625

20. Sack J, Fisher DA, Wang CC 1976 Serum thyrotropin, prolactin, and growth hormone levels during the early neonatal period in the human infant. $J$ Pediatr 89:298-300

21. Klein AH, Foley B, Kenny FM, Fisher DA 1979 Thyroid hormone and thyrotropin responses to parturition in premature infants with and without the respiratory distress syndrome. Pediatrics 63:380-385

22. Chopra IJ, Solomon DH, Beall GN 1971 Radioimmunoassay for measurement of triiodothyronine in human serum. J Clin Invest 50:2033-2041

23. Jackson IM 1982 Thyrotropin-releasing hormone. N Engl J Med 306:145-155

24. Snyder PJ, Utiger P 1972 Response to thyrotropin releasing hormone (TRH) in normal man. $\mathrm{J}$ Clin Endocrinol 34:380-385

25. Ylikorkala O, Kivinen S, Reinila M 1979 Serial prolactin and thyrotropin 
responses to thyrotropin-releasing hormone throughout normal human pregnancy. J Clin Endocrinol Metab 48:288-292

26. Kulseng-Hanssen S, Torjesen PA, Hanssen KF 1979 Serum prolactin and thyroid stimulating hormone levels following thyrotropin releasing hormone stimulation in preeclamptic patients. Acta Obstet Gynecol Scand 58:245248

27. Miyamoto J 1984 Prolactin and thyrotropin responses to thyrotropin-releasing hormone during the peripartal period. Obstet Gynecol 63:639-644

28. Hotelling DR, Sherwood LM 1971 The effects of pregnancy on circulating triiodothyronine. J Clin Endocrinol 33:783-786

29. Fisher DA, Dussault JH, Erenberg A, Lam RW 1972 Thyroxine and triiodothyronine metabolism in maternal and fetal sheep. Pediatr Res 6:894-899-

30. Fisher DA, Dussault JH, Sack J, Chopra IJ 1977 Ontogenesis of hypothalamicpituitary-thyroid function and metabolism in man, sheep, and rat. Recent Prog Horm Res 33:59-116

31. Roti E, Fang S, Green K, Emerson C, Braverman L 1981 Human placenta is an active site of thyroxine and 3,3',5-triiodothyronine tyrosyl ring deiodination. J Clin Endocrinol Metab 53:498-501.

32. Fisher D 1983 Maternal-fetal thyroid function in pregnancy. Clin Perinatol 10:615-626.

33. Sack J, Mashiach S, Barkai G, Siowitch A, Feldman J, Lusky A, Goldman B, Brish M 1983 Thyroid function in prematures (PM) treated and not treated prenatally to enhance lung maturity. The Endocrine Society. Program and abstracts, p 281

34. Neary JT, Nakamura C, Davies IJ, Soodak M, Maloof F 1978 Lower levels of thyrotropin-releasing hormone degrading activity in human cord and in maternal sera than in the serum of euthyroid, non-pregnant adults. $\mathbf{J}$ Clin Invest $62: 1-5$

35. Cuestas RA 1978 Thyroid function in healthy premature infants. J Pediat 92:963-967

36. Sack J, Beaudry M, DeLamater PV, Oh W, Fisher DA 1976 Umbilical cord cutting triggers hypertriodothyroninemia and non-shivering thermogenesis in the newborn lamb. Pediatr Res 10:169-175

37. Fisher DA, Klein AH 1980 The ontogenesis of thyroid function and its relationship to neonatal thermogenesis. In: Tulchinsky D, Ryan $\mathrm{KJ}$ (eds) Maternal-Fetal Endocrinology. WB Saunders Company, Philadelphia, pp 281-293

38. Liggins GC, Schellenberg JC 1985 Aspects of fetal lung development. In: Jones CT (ed) The Physiological Development of the Fetus and Newborn. Academic Press, London, pp 179-189

39. Jacobsen B, Anderson H, Dige-Petersen H, Hummer L 1977 Pituitary-thyroid responsiveness to thyrotropin-releasing hormone in preterm and small-forgestational-age newborns. Acta Paediatr Scand 66:541-548

40. Osathanondh R, Chopra IJ, Tulchinsky D 1978 Effects of dexamethasone on fetal and maternal thyroxine, triiodothyronine, reverse triiodothyronine, and thyrotropin levels. J Clin Endocrinol Metab 47:1236-1239 